

\title{
2-Arylvinylpyrimidines versus 4-arylvinylpyrimidines: synthesis and comparison of the optical properties.
}

\author{
Sylvain Achelle, Françoise Robin-Le Guen
}

\section{To cite this version:}

Sylvain Achelle, Françoise Robin-Le Guen. 2-Arylvinylpyrimidines versus 4-arylvinylpyrimidines: synthesis and comparison of the optical properties.. Tetrahedron Letters, 2013, 54 (33), pp.4491-4496. 10.1016/j.tetlet.2013.06.040 . hal-00915008

\section{HAL Id: hal-00915008 \\ https://hal.science/hal-00915008}

Submitted on 6 Dec 2013

HAL is a multi-disciplinary open access archive for the deposit and dissemination of scientific research documents, whether they are published or not. The documents may come from teaching and research institutions in France or abroad, or from public or private research centers.
L'archive ouverte pluridisciplinaire HAL, est destinée au dépôt et à la diffusion de documents scientifiques de niveau recherche, publiés ou non, émanant des établissements d'enseignement et de recherche français ou étrangers, des laboratoires publics ou privés. 


\section{Graphical abstract:}

2-Arylvinylpyrimidines versus 4Arylvinylpyrimidines: Synthesis and comparison of the optical properties.

S. Achelle, and F. Robin-le Guen

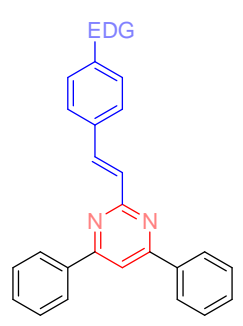
Leave this area blank for abstract info.






\title{
2-Arylvinylpyrimidines versus 4- Arylvinylpyrimidines: Synthesis and comparison of the optical properties.
}

\author{
Sylvain Achelle, ${ }^{*}$ and Françoise Robin-le Guen. ${ }^{1}$ \\ ${ }^{1}$ Institut des Sciences Chimiques de Rennes UMR CNRS 6226, IUT de Lannion, rue Edouard \\ Branly, BP 30219, F22302 Lannion Cedex, France. \\ Corresponding author: Tel : +33 (0)2 96469448 Fax : + 33 (0)2 96469354 E-mail : \\ sylvain.achelle@univ-rennes1.fr
}

\begin{abstract}
Condensation of donor-substituted aldehydes on methylpyrimidine led to two series of fluorescent molecules depending on the position of the methyl group. Whereas highly emissive 4-arylvinylpyrimidine derivatives are well-known, this is the first example of fluorescent 2-arylvinylpyrimidine compounds. The optical properties of the two families have been thoroughly compared. Whereas the series derived from 2-methylpyrimidine exhibit a blue shift in absorption and emission in comparison with 4-arylvinylpyrimidine, the influence of the position is less predictable on the fluorescence quantum yield. These compounds exhibit also halochromism: when adding acid, a bathotromic shift is observed in absorption whereas an increase of the fluorescence intensity which is red-shifted except for amino derivatives (a progressive quench of emission is observed in these cases). An emission solvatochromism study has shown that a higher intramolecular charge transfer seems to occur in 2-arylvinylpyrimidines than in 4-arylvinylpyrimidines.
\end{abstract}


Key words: Pyrimidine, Photoluminescence, Intramolecular Charge Transfer, Condensation, Dyes.

During the past decades, there has been a great interest in the synthesis of $\pi$-conjugated pyrimidine derivatives due to the potential applications in optoelectronics. ${ }^{1}$ Indeed the pyrimidine, which is a highly $\pi$-deficient aromatic heterocycle, can be used as electron withdrawing part in push-pull structures for intramolecular charge transfert (ICT). An important ICT is a key parameter to obtain luminescent and Non Linear Optical (NLO) properties.

Since their first design by Vanden Eynde and coworkers in $2001,{ }^{2}$ 4,6-diarylvinylpyrimidines have become a well established design for luminescent dyes with sensing applications ${ }^{3}$ second order NLO materials ${ }^{4}$ and Two Photon Absorption (TPA) chromophores. ${ }^{5}$ Recently we have also described 4-arylvinylpyrimidines that can be used as metal cation sensors, ${ }^{6}$ duplex DNA sensors $^{7}$ and second order NLO chromophores. ${ }^{8}$

Even if some 2-arylvinylpyrimidines have been described for their biological activities, ${ }^{9}$ to the best of our knowledge, the photophysical properties of these derivatives have not been studied.

In continuation of our work dedicated to diazine dyes, the aim of this paper is to describe the synthesis and photophysical properties of two series of 2- and 4-arylvinylpyrimidines. The two families of molecules will be thoroughly compared in term of absorption and emission properties.

Two main methods have been described for the synthesis of $(E)$-arylvinylpyrimidines: The use of cross coupling reactions with halogenopyrimidines ${ }^{10}$ and the condensation of aldehyde with methylpyrimidines. ${ }^{2,3 a, 4,5 a-f, 6 a, 8}$ The latter approach has the advantages of a wide range of commercially available aldehydes and the use of environmentally friendly conditions in most cases. 
Taking into account the fact that 2-methylpyrimidine is not commercially available or easy to synthesize, it has been chosen to work with diphenyl derivatives $\mathbf{2}$ and $\mathbf{4}$. These compounds can be easily obtained by Suzuki cross-coupling reaction ${ }^{11}$ from easily available 4,6-dichloro2-methylpyrimidine 1 and 2,4-dichloro-6-methylpyrimidine 3 (Scheme 1). It should be noted that the $\pi$-electron deficient character of the pyrimidine ring make easier the oxidative addition of palladium to a chlorine-carbon bond in position 2, 4 and 6 without the use of specialized and expensive ligands. ${ }^{12}$ Nevertheless the addition of palladium it a bit more difficult in position 2 and require a longer reaction time (24h for compound 2 vs 48 h for compound 4$).{ }^{13}$<smiles>Cc1nc(Cl)cc(Cl)n1</smiles>

1

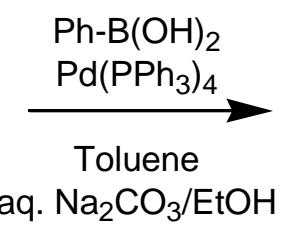

$\Delta 24 \mathrm{~h}$<smiles>Cc1cc(Cl)nc(Cl)n1</smiles>

3

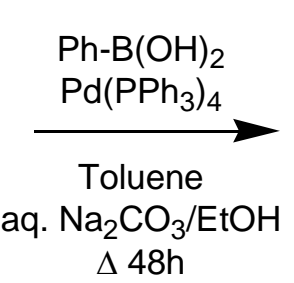

$\triangle 48 h$<smiles>Cc1nc(-c2ccccc2)cc(-c2ccccc2)n1</smiles>

$281 \%$<smiles>Cc1cc(-c2ccccc2)nc(-c2ccccc2)n1</smiles>

$494 \%$

\section{Scheme 1.}

The synthesis of aryvinylpyrimidines $\mathbf{5}$ and $\mathbf{6}$ has been carried out by condensation reaction between the methylpyrimidines 2 and 3 para-substituted benzaldehyde in boiling aqueous $5 \mathrm{M}$ $\mathrm{NaOH}$ using Aliquat $^{\circledR} 336$ as a phase transfer catalyst according the method initially described by Vanden Eynde (Scheme 2 and 3). ${ }^{14}$ Compounds 5 and $\mathbf{6}$ have been obtained with moderate to good yield. It should be noted that no significant difference in reactivity has been observed between methyl in positions 2 and 4 of the pyrimidine ring. 




\section{Scheme 2.}<smiles>Cc1cc(-c2ccccc2)nc(-c2ccccc2)n1</smiles>

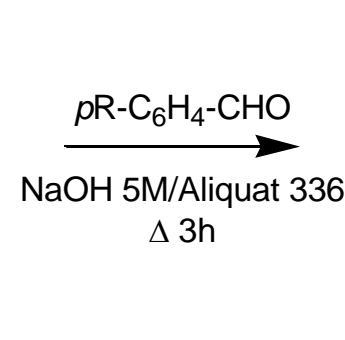<smiles>Brc1ccc(/C=C/c2cc(-c3ccccc3)nc(-c3ccccc3)n2)cc1</smiles>

6a $\mathrm{R}=\mathrm{OMe} 56 \%$

6b $\mathrm{R}=\mathrm{SMe} 48 \%$

6c $\mathrm{R}=\mathrm{NMe}_{2} 54 \%$

$6 \mathbf{d} \mathrm{R}=\mathrm{NPh}_{2} 76 \%$

\section{Scheme 3.}

The UV-Vis and photoluminescence (PL) spectroscopic data of compounds 5 and $\mathbf{6}$ measured in dichloromethane at $25^{\circ} \mathrm{C}$ are presented in table 1 . Analyses have been carried out using low concentration solutions $\left(1.0 \times 10^{-5}\right.$ to $3.0 \times 10^{-5} \mathrm{M}$ for UV/Vis spectra and $1.0 \times 10^{-6}$ to $3.0 \mathrm{x}$ $10^{-6} \mathrm{M}$ for PL spectra). As an example, the spectra for derivatives $\mathbf{5 d}, \mathbf{6 a}$ and $\mathbf{6 d}$ are shown in Figure 1. Under these conditions, self-absorption effects were not observed. All compounds are photostable and did not undergo cis-trans isomerization under the analysis conditions.

All the compounds exhibit two absorption bands. The most energetic one is located in the 252-276 $\mathrm{nm}$ range, the less energetic one $\left(\lambda_{\mathrm{abs}}=326-411 \mathrm{~nm}\right)$ is attributed to a charge transfer transition. Compounds $\mathbf{6}$ are slightly red shifted in comparison with 4-arylvinylpyrimidines that are not substituted in positions 2 and 6 of the pyrimidine ring. ${ }^{8}$ It should be noted that the less energetic band is blue shifted $\left(\Delta \lambda_{\text {abs }}=16-25 \mathrm{~nm}\right)$ for 2-arylvinylpyrimidines 5 in comparison with 4-arylvinylpyrimidines 6. This is a bit more difficult to rationalize the emission results: Whereas some subtituents $\left(\mathrm{SMe}\right.$ and $\left.\mathrm{NPh}_{2}\right)$ lead to an important hypsochromic shift (up to $30 \mathrm{~nm}$ ) on the emission band of the 2-arylvinylpyrimidines $(\mathbf{5 b}$ and 5d) in comparison with 4-arylvinylpyrimidines ( $6 \mathbf{b}$ and $\mathbf{6 d}$ ), the other substituents (OMe, 
$\mathrm{NMe}_{2}$ and piperidinyl) do not conduct to significant modification of the emission maxima. In term of emission intensity, the 2-arylvinylpyrimidines $\mathbf{5}$ exhibit lower fluorescent quantum yield compared with 4-arylvinylpyrimidines 6, excepted for the diphenylamino derivatives: in that case the 2-arylvinylpyrimidines $\mathbf{5 d}\left(\Phi_{\mathrm{F}}=0.71\right)$ exhibit a two-time higher quantum yield than the 4-arylvinylpyrimidines 6d. Taking into account the absorption and the emission shifts, the Stokes shifts are generally higher for compounds 5 than for compound $\mathbf{6}$.



Figure 1: Normalized UV/vis (solid line) and emission spectra (brocken line) of compounds 5d (green), 6a (red) and 6d (blue).

Table 1. UV/Vis and photoluminescence (PL) data

\begin{tabular}{ccccc}
\hline & UV/vis $\lambda_{\max }, \mathrm{nm}$ & $\mathrm{PL}$ & & Stokes shift $^{\mathrm{c}}$ \\
$\mathrm{Compd}^{a}$ & $\left(\varepsilon, \mathrm{mM}^{-1} \cdot \mathrm{cm}^{-1}\right)$ & $\lambda_{\max }, \mathrm{nm}$ & $\Phi_{\mathrm{F}}^{\mathrm{b}}$ & $\mathrm{cm}^{-1}$ \\
\hline $\mathbf{5 a}$ & $276(28.2), 326(25.1)$ & 426 & 0.009 & 7201 \\
$\mathbf{5 b}$ & $263(27.4), 337(16.5)$ & 429 & 0.024 & 6364 \\
\hline
\end{tabular}




\begin{tabular}{rlccc}
\hline $\mathbf{5 c}$ & $261(35.4), 383(23.9)$ & 519 & 0.062 & 6842 \\
$\mathbf{5 d}$ & $276(31.2), 395(19.9)$ & 499 & 0.71 & 5276 \\
$\mathbf{5 e}$ & $260(40.3), 376(31.0)$ & 524 & 0.057 & 7511 \\
$\mathbf{6 a}$ & $252(49.3), 351(20.0)$ & 430 & 0.002 & 5234 \\
$\mathbf{6 b}$ & $261(42.0), 359(15.6)$ & 449 & 0.044 & 5583 \\
$\mathbf{6 c}$ & $260(41.1), 406(26.2)$ & 520 & 0.14 & 5400 \\
$\mathbf{6 d}$ & $268(24.2), 411(16.2)$ & 525 & 0.35 & 5283 \\
$\mathbf{6 e}$ & $260(33.6), 397(22.5)$ & 522 & 0.22 & 6031 \\
\hline
\end{tabular}

${ }^{a}$ All spectra were recorded in $\mathrm{CH}_{2} \mathrm{Cl}_{2}$ solutions at room temperature at $c=1.0 \times 10^{-5} \mathrm{M}$ to 3.0 $\times 10^{-5} \mathrm{M}$ for absorption and $c=1.0 \times 10^{-6} \mathrm{M}$ to $3.0 \times 10^{-6} \mathrm{M}$ for emission. ${ }^{b}$ Fluorescence quantum yield $( \pm 10 \%)$ determined relative to quinine sulfate in $1 \mathrm{M} \mathrm{H}_{2} \mathrm{SO}_{4}\left(\Phi_{\mathrm{F}}=0.54\right)$.c calculated using the less energetic absorption band

In previous studies, ${ }^{3 a, 6 a, 7,8}$ we demonstrated the ability of related 4-(arylvinyl)pyrimidines to function as colorimetric and luminescent $\mathrm{pH}$ sensors due to the basic character of the nitrogen atoms of the pyrimidine ring. For this reason, we decided to study the effect of protonation on the optical properties of several of the prepared arylvinyldiazines (5d and $\mathbf{6 d})$. Dichloromethane solutions of these compounds underwent a significant color change in the presence of TFA $\left(10^{-2} \mathrm{M}\right)$ (Figure 2). As expected, the compounds exhibit a bathochromic shift of their absorption bands upon protonation due to an increased charge transfer from the donors to the pyrimidinium moiety. This color change is fully reversible by neutralization with a base such as $\mathrm{Et}_{3} \mathrm{~N}$ or $\mathrm{KBu}^{\mathrm{t}} \mathrm{O}$. 

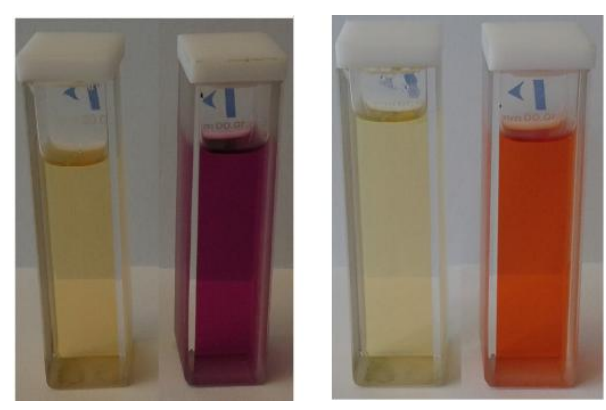

Figure 2: color change of $\mathrm{CH}_{2} \mathrm{Cl}_{2}$ solutions of compounds $5 \mathrm{~d}$ (left) and $6 \mathrm{~d}$ (right) $\left(\mathrm{c}=\mathbf{1 0}^{-}\right.$ ${ }^{3} \mathrm{M}$ in the presence of $10^{-2} \mathrm{M}$ TFA)

The changes in the UV-Vis spectra of $\mathbf{5 d}$ and $\mathbf{6 d}$ upon progressive addition of acid are illustrated in Figures 3 and 4. The spectra show the progressive attenuation of the absorption band for the neutral compound on increasing the concentration of acid, whereas a new redshifted band corresponding to the protonated species appeared. It should be noted that for compound $\mathbf{6 d}$, for a concentration of TFA $=10^{-2} \mathrm{M}$ and even more for a concentration of TFA $=10^{-1} \mathrm{M}$, absorption band is red-shifted probably due to the impact of the increasing solvent polarity $\left(\mathrm{CH}_{2} \mathrm{Cl}_{2}+\mathrm{TFA}\right)$ on the highly polar protonated compound. ${ }^{15}$ As described in Table 2, a red shift of the absorption band is observed upon addition of TFA $\left(\mathrm{c}=10^{-2} \mathrm{M}\right)$ except for compounds $\mathbf{6 c}$ and $\mathbf{6 e}$ bearing protonable amino group: in these cases a blue shift of the absorption band is observed. Such phenomena has been already observed with arylvinyldiazine substituted with amino groups. ${ }^{8,16}$ It should be noted that the same blue shift is not observed for compounds $\mathbf{5 c}$ and $\mathbf{5 e}$. 


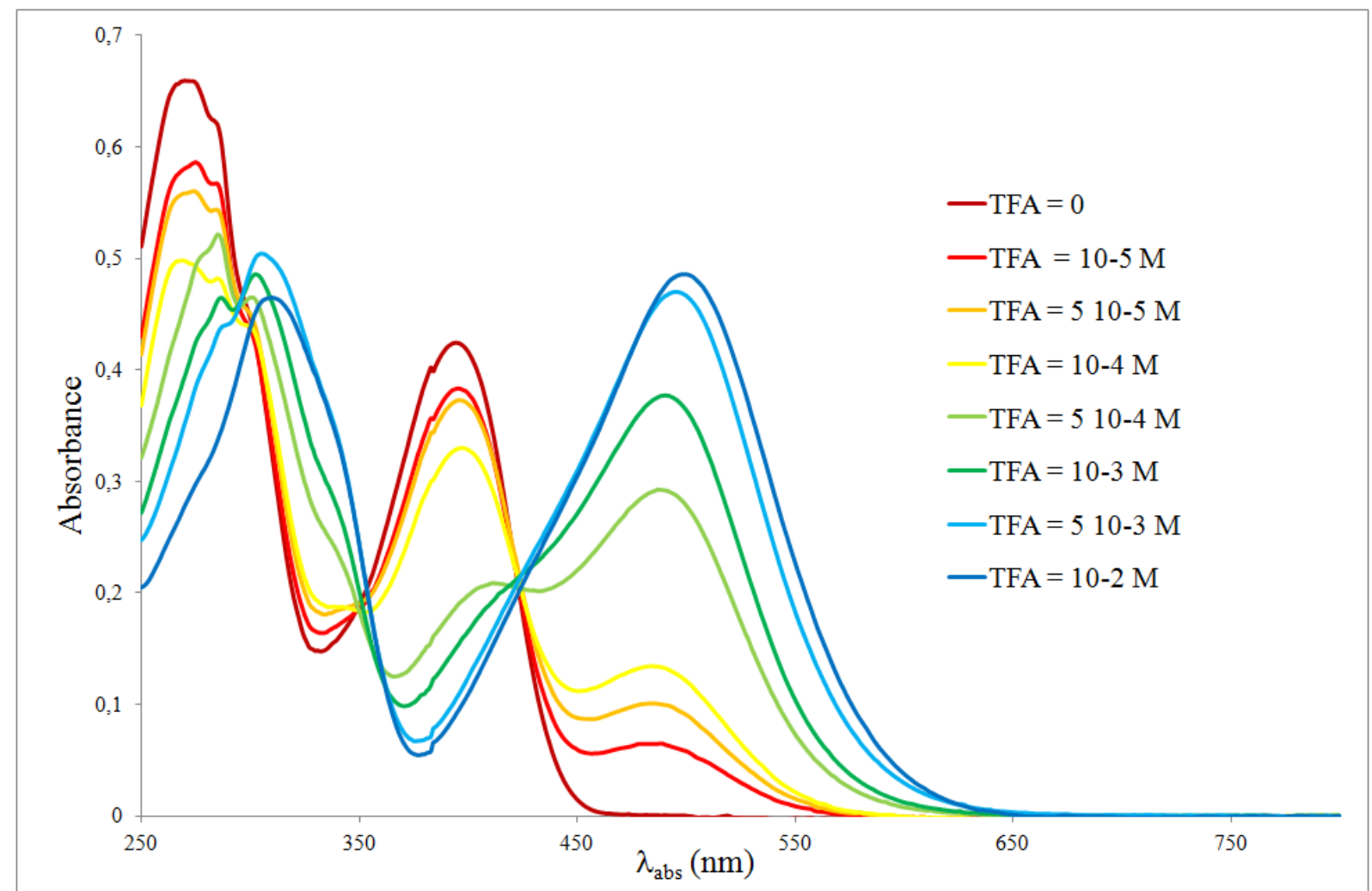

Figure 3. Change in the absorption spectra of $5 \mathrm{~d}\left(\mathrm{c}=210^{-5} \mathrm{M}\right)$ upon addition of TFA $\left(10^{-5} \mathrm{M}\right.$ to $\left.10^{-2} \mathrm{M}\right)$

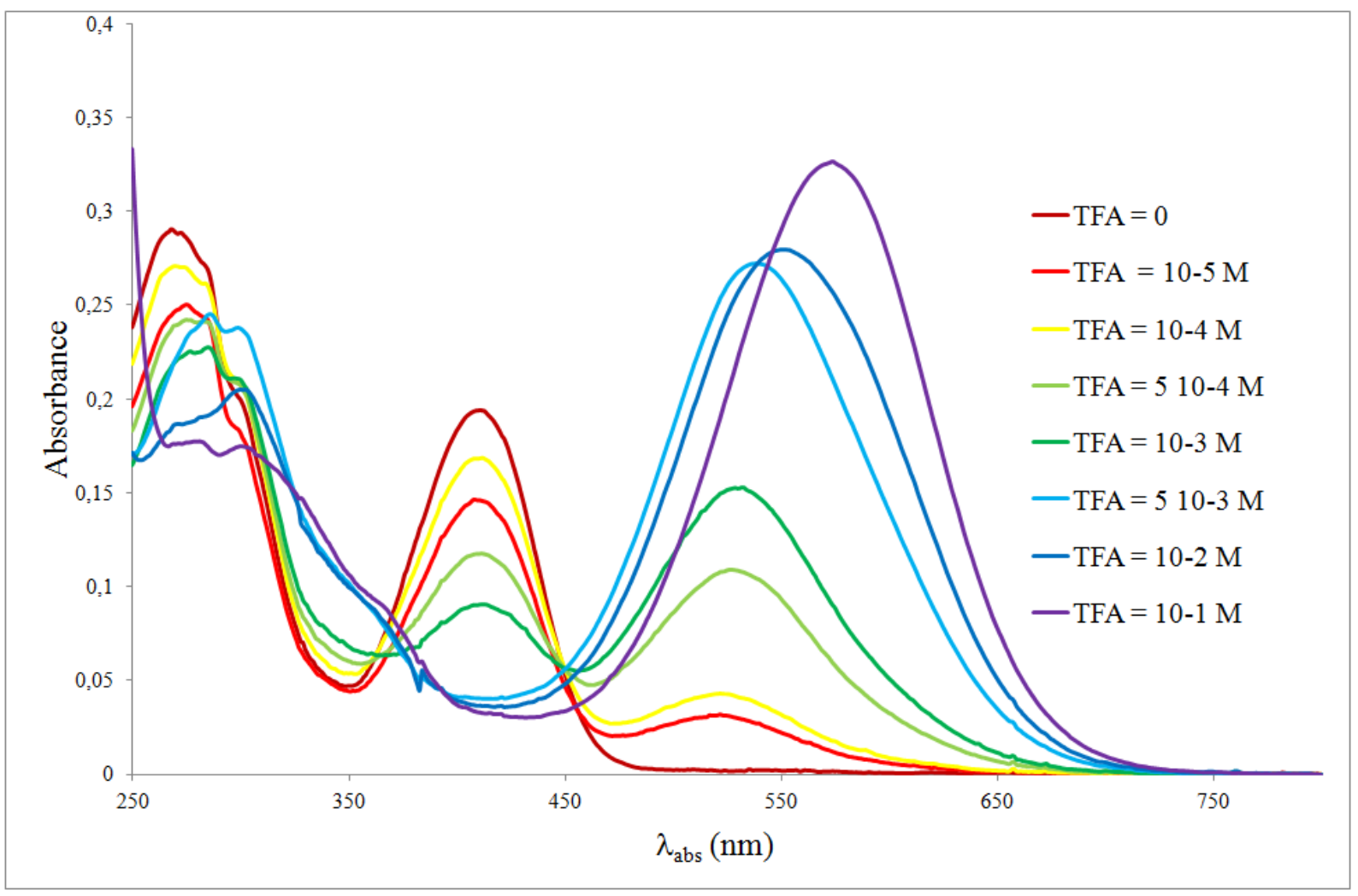


Figure 4. Change in the absorption spectra of $6 \mathrm{~d}\left(\mathrm{c}=1.210^{-5} \mathrm{M}\right)$ upon addition of TFA $\left(10^{-5} \mathrm{M}\right.$ to $\left.10^{-1} \mathrm{M}\right)$

Table 2. Comparison of the position of the less energetic absorption band upon addition of TFA

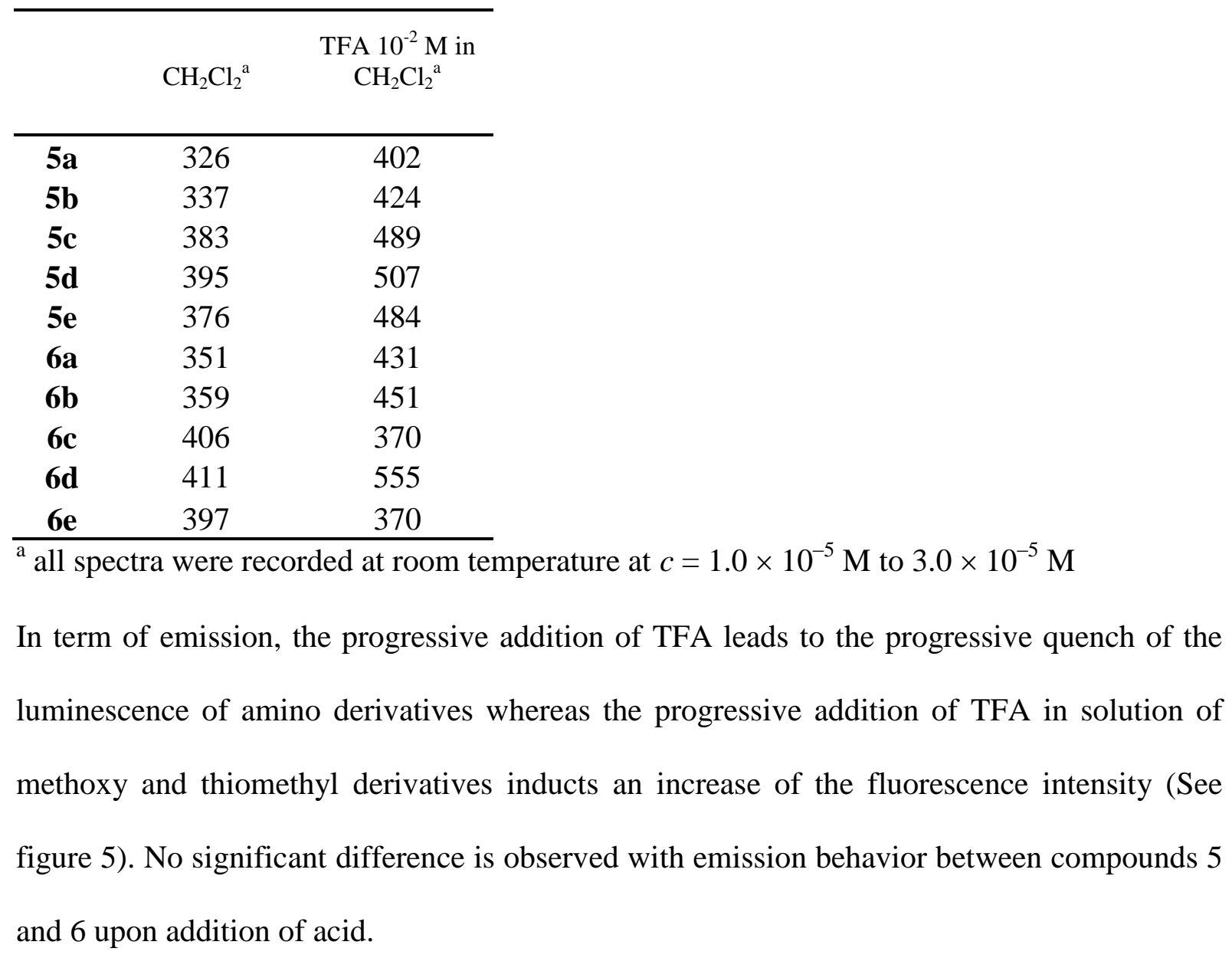




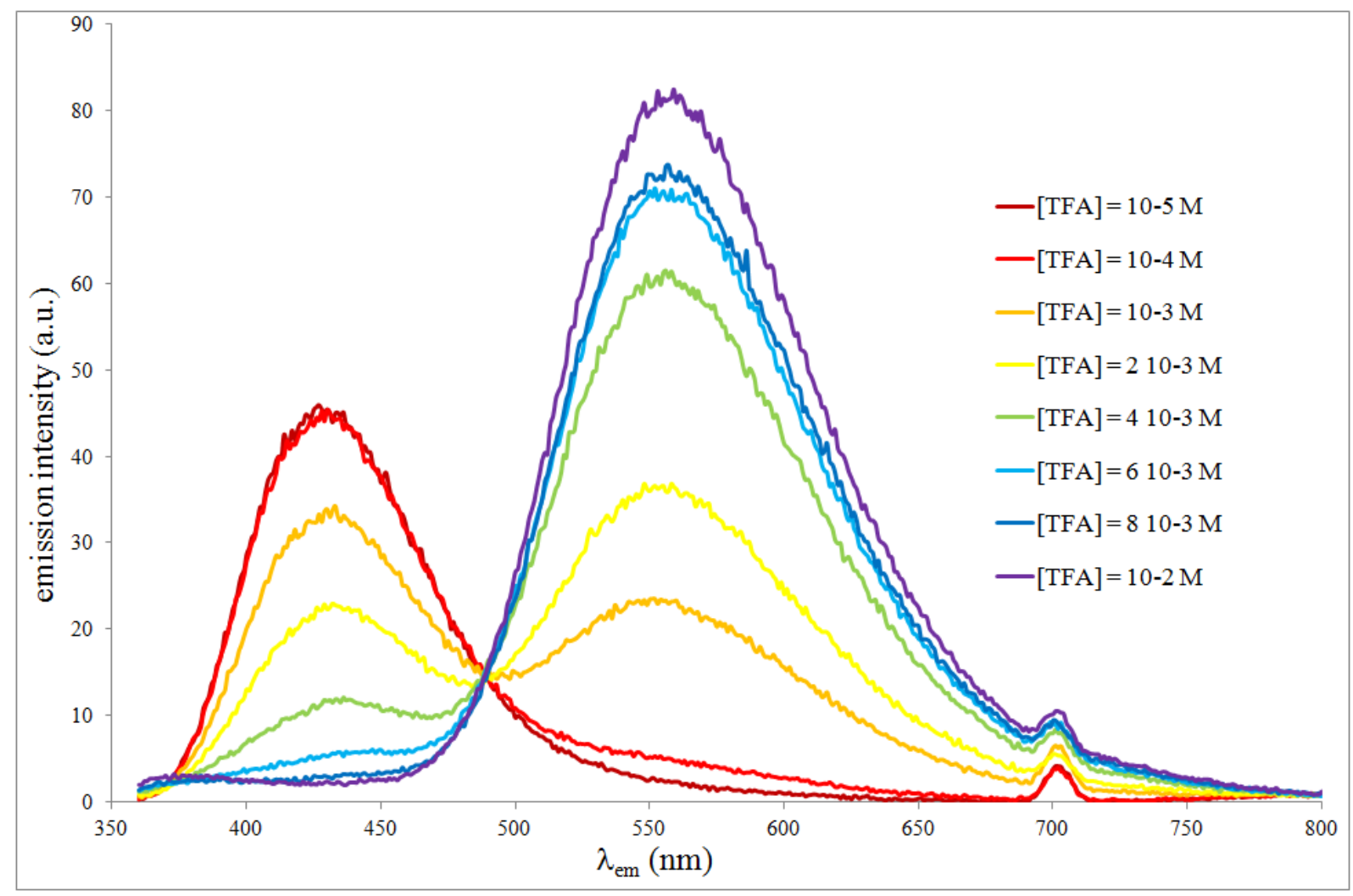

Figure 5. Change in the emission spectra of $5 \mathrm{a}\left(\mathrm{c}=210^{-6} \mathrm{M}\right)$ upon addition of TFA $\left(10^{-5}\right.$ $M$ to $\left.10^{-2} \mathrm{M}\right)$, excitation at $350 \mathrm{~nm}$.

In an effort to gain further insight into the photophysical process within these pushpull molecules, we investigated the emission behaviors of compounds $\mathbf{5}$ and $\mathbf{6}$ in different aprotic solvents. The results of these investigations are summarized in Table 3. As an example the emission spectra in various solvents for compound 5d are shown in Figure 6. For all compounds, a bathochromic shift of the emission band is observed with increasing solvent polarity as predicted by Dimroth-Reichardt polarity parameter $\left(\Delta \mathrm{E}_{\mathrm{T}}(30)\right) .{ }^{17}$ In contrast, the absorption wavelength is not significantly shifted. Broad structureless emission and larger Stokes shifts were observed for polar solvents. The correlation of the emission maxima with $\Delta \mathrm{E}_{\mathrm{T}}(30)$ is represented in Figure 7 and in supporting information and was found to be positively linear for all the compounds. This solvatochromic behavior, which results from the stabilization of the highly polar emitting state by polar solvents, is typical for compounds exhibiting an internal charge transfer upon excitation and has been fully documented with 
donor-acceptor fluorophores. ${ }^{18}$ When comparing for each substituent the emission solvatochromic range expressed as a wave number for 2-arylvinylpyrimidines 5 and 4arylvinylpyrimidines $\mathbf{6}$, it appears that this range is much higher for compounds $\mathbf{5}$ than for compounds 6. Moreover the slope of the emission maxima versus $\Delta \mathrm{E}_{\mathrm{T}}(30)$ is higher for 2arylvinylpyrimidine $\mathbf{5}$ than for 2-arylvinylpyrimidine $\mathbf{6}$ for each substituent. This seems to indicate that the internal charge transfer is more important in compounds $\mathbf{5}$ than in compounds 6 and therefore that 2-substituted pyrimidine is a better electron-accepting group than 4substituted pyrimidine. It should be noted that in polar solvent for amino derivatives $\mathbf{5 c}$ and 5d the emission intensity decreases dramatically, it was not observed with the other compounds studied.

TABLE 3. Emission solvatochromic range of arylvinylpyrimidines 5 and 6 in various aprotic solvents

\begin{tabular}{ccccccc}
\hline & $\begin{array}{c}n \text {-heptane } \\
\Delta \mathrm{E}_{\mathrm{T}}(30)^{\mathrm{a}}=0.0\end{array}$ & $\begin{array}{c}\mathrm{THF} \\
\Delta \mathrm{E}_{\mathrm{T}}(30)^{\mathrm{a}}=27.2\end{array}$ & $\begin{array}{c}\mathrm{CH}_{2} \mathrm{Cl}_{2} \\
\Delta \mathrm{E}_{\mathrm{T}}(30)^{\mathrm{a}}=40.7\end{array}$ & $\begin{array}{c}\text { Acetone } \\
\Delta \mathrm{E}_{\mathrm{T}}(30)^{\mathrm{a}}=42.2\end{array}$ & $\begin{array}{c}\text { DMSO } \\
\Delta \mathrm{E}_{\mathrm{T}}(30)^{\mathrm{a}}=59.0\end{array}$ & $\begin{array}{c}\Delta v^{\mathrm{b}} \\
\text { in } \mathrm{cm}^{-1}\end{array}$ \\
\hline $\mathbf{5 a}$ & 392 & 425 & 426 & 435 & 463 & 3912 \\
$\mathbf{5 b}$ & 399 & 426 & 429 & 440 & 460 & 3323 \\
$\mathbf{5 c}$ & 441 & 512 & 519 & 568 & 587 & 5070 \\
$\mathbf{5 d}$ & 420 & 480 & 499 & 504 & 526 & 4790 \\
$\mathbf{5 e}$ & 450 & 518 & 524 & 563 & 591 & 5301 \\
$\mathbf{6 a}$ & 403 & 428 & 430 & 436 & 456 & 2884 \\
$\mathbf{6 b}$ & 415 & 445 & 449 & 459 & 475 & 3044 \\
$\mathbf{6 c}$ & 448 & 508 & 520 & 531 & 554 & 4270 \\
$\mathbf{6 d}$ & 485 & 508 & 525 & 528 & 551 & 2469 \\
$\mathbf{6 e}$ & 461 & 511 & 522 & 535 & 552 & 3576 \\
\hline
\end{tabular}

${ }^{a}$ Dimroth-Reichardt polarity parameter, $\mathrm{J} \cdot \mathrm{mol}^{-1} \cdot{ }^{\mathrm{b}} \Delta v=v($ heptane $)-v($ DMSO $)$ 


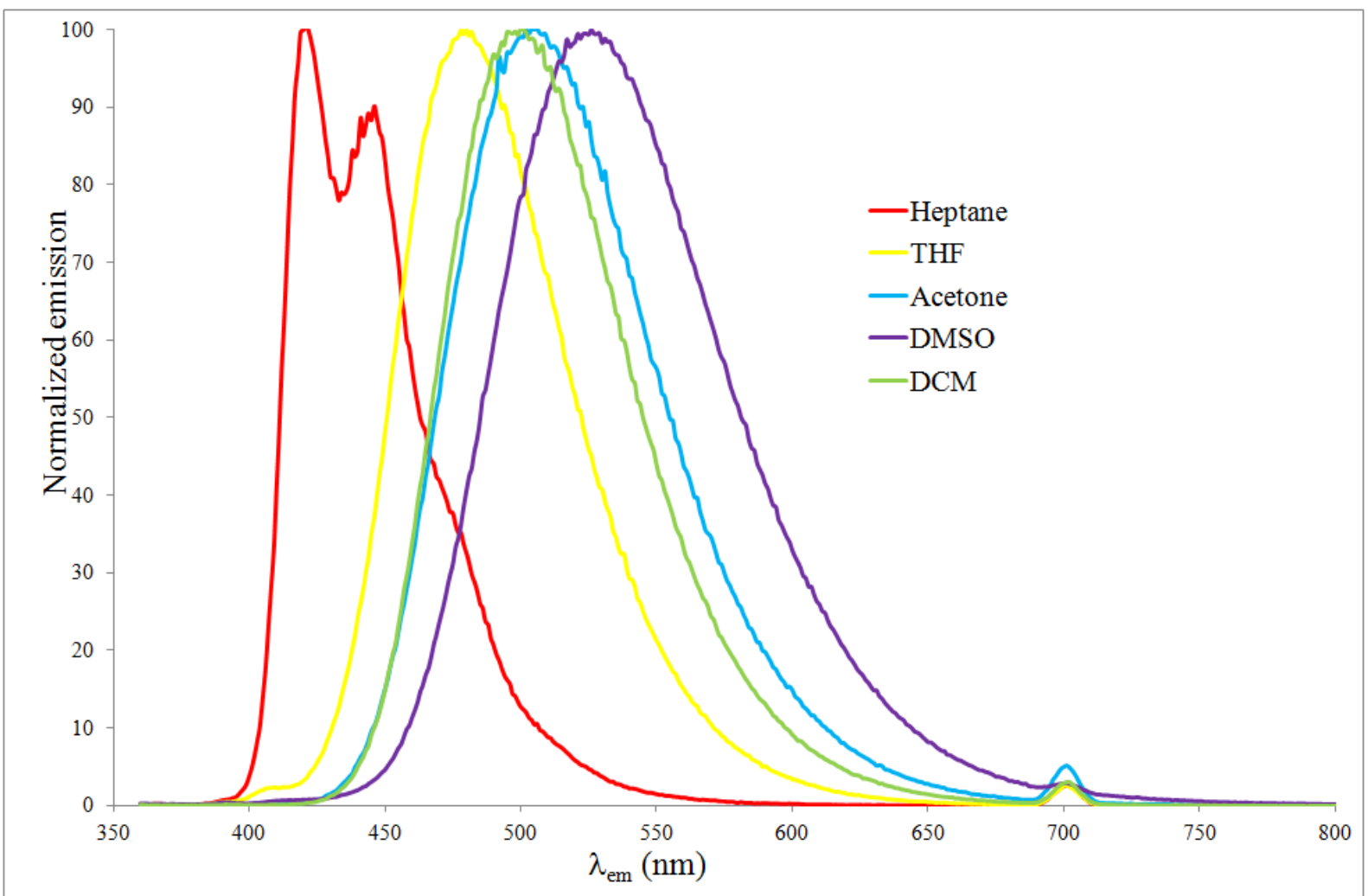

Figure 6 : Normalized emission of compound $5 \mathrm{~d}$ in various solvents $\left(c=210^{-6} \mathrm{M}\right)$

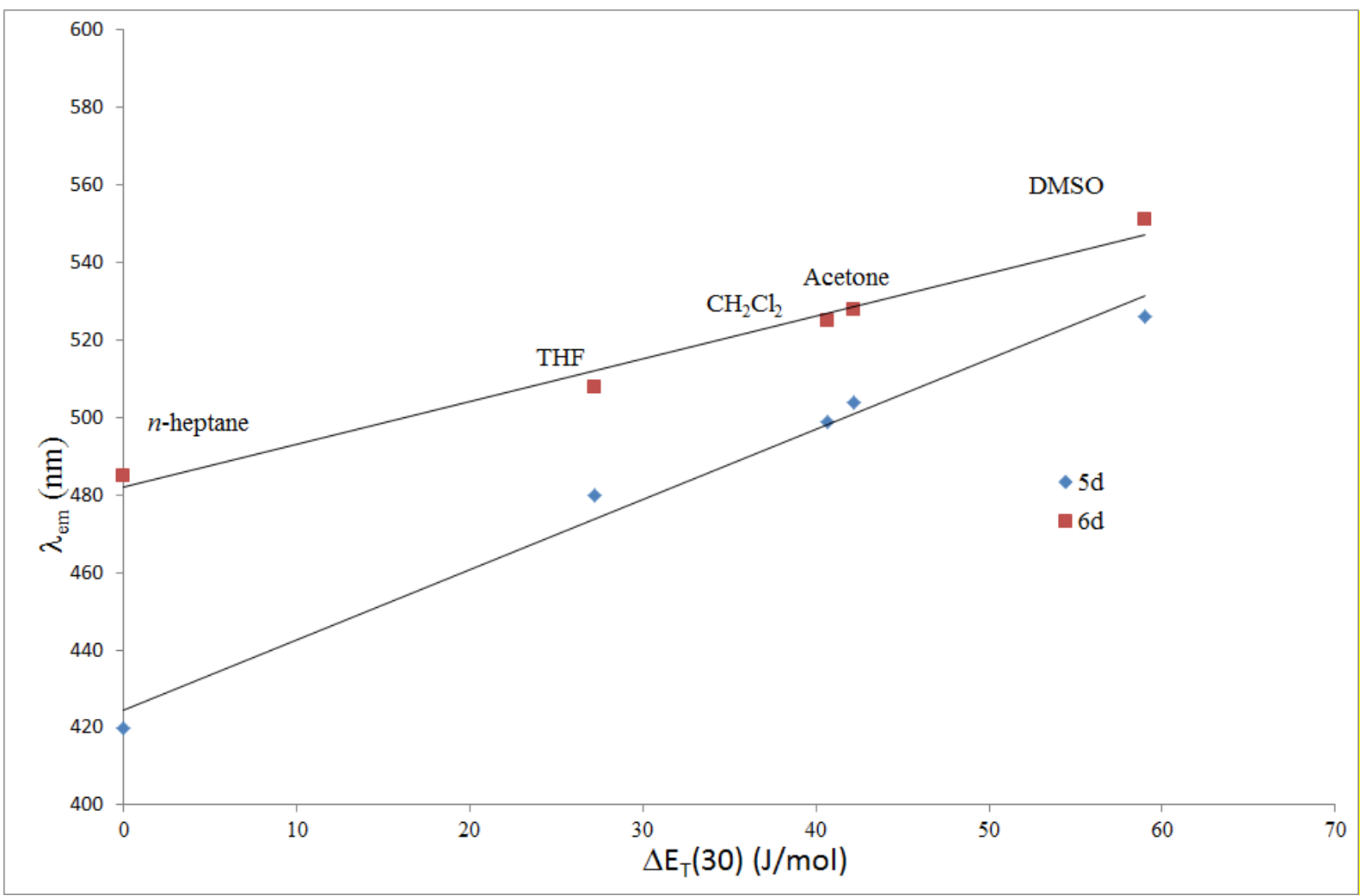

Figure 7: Emission wavelength $\left(\lambda_{\max }\right)$ as a function of Dimroth-Reichart polarity parameter for compounds $5 \mathrm{~d}$ and $6 \mathrm{~d}$. 
To conclude, we have efficiently synthesized two series of donor substituted arylvinylpyrimidines from 4-methyl and 2-methylpyrimidine derivatives. This is the first example for condensation of aldehyde on 2-methylpyrimidine derivatives. We have shown that the absorption and emission maxima are generally blue shifted in case of 2arylvinylpyrimidines 5 when compared with 4-arylvinylpyrimidines $\mathbf{6}$. The influence of the position is less predictable in term of quantum yield. Similar halochromism phenomena have been observed in the two series of molecules. An emission solvatochromism study has shown that a higher intramolecular charge transfer seems to occur in 2-arylvinylpyrimidines 5 than 4arylvinylpyrimidines 6. Donor substituted 2-arylvinylpyrimidines seem therefore to be really interesting structures for NLO properties. Investigations in this direction are currently carried out.

\section{Acknowledgements}

We acknowledge Pr. Bertrand Caro for helpful discussion. We thank the UMR176 at Institut Curie for the access to the spectrophotometers.

\section{Supplementary data}

Supplementary data (experimental details, spectroscopic data, copies of ${ }^{1} \mathrm{H}$ and ${ }^{13} \mathrm{C}$ ) can be found in the online version.

${ }^{1}$ Achelle, S.; Plé, N. Curr. Org. Synth. 2012, 9, 163-187.

${ }^{2}$ a) Pascal, L.; Vanden Eynde, J.-J.; Van Haverbeke, Y.; Dubois, P.; Michel, A.; Rant, U.; Zojer, E.; Leising, G.; Van Dorm, L. O.; Gruhn, N. E.; Cornil, J.; Brédas, J.-L. J. Phys. Chem. B 2002, 106, 6442-6450. b) Pascal, L.; Vanden Eynde, J.-J.; Van Haverbeke, Y.; Dubois, P.; Michel, A.; Rant, U.; Zojer, E.; Leising, G.; Lazzaroni R.; Cornil, J.; Brédas, J.-L. Synth. Met. 2001, 119, 183-184. 
${ }^{3}$ a) Achelle, S.; Nouira, I.; Pfaffinger, B.; Ramondenc, Y.; Plé, N.; Rodríguez-López, J. J. Org. Chem. 2009, 74, 3711-3717. b) Vurth, L.; Hadad, C.; Achelle, S.; García-Martinez, J.; Rodríguez-López, J.; Stephan, O. Colloid Polym. Sci. 2012, 290, 1353-1359. b) Boländer, A.; Kieser, D.; Voss, C.; Bauer, S.; Schön, C.; Burgold, S.; Bittner, T.; Hölzer, J.; Heyny-von Haußen, R.; Mall, G.; Goetschy, V.; Czech, C.; Knust, H.; Berger, R.; Herms, J.; Hilger, I.; Schmidt, B. J. Med. Chem. 2012, 55, 9170-9180.

${ }^{4}$ Akdas-Kilig, H.; Roisnel, T.; Ledoux, I.; Le Bozec, H.; New J. Chem. 2009, 33, 1470-1473.

5 a) Liu, Z.; Shao, P.; Huang, Z.; Liu, B.; Chen, T.; Qin, J. Chem. Commun. 2008, 2260-2262.

b) Li, L.; Tian, Y. P.; Yang, J. X.; Sun, P. P.; Wu, J. Y.; Zhou, H. P.; Zhang, S. Y.; Jin, B. K.; Xing, X. J.; Wang, C. K.; Li, M.; Cheng, G. H.; Tang, H. H.; Huang, W. H.; Tao, X. T.; Jiang, M. H. Chem. Asian J. 2009, 4, 668-680. c) Liu, Z.; Chen, T.; Liu, B.; Huang, Z.-L.; Huang, T.; Li, S.; Xu, Y.; Qin, J. J. Mater. Chem. 2007, 17, 4685-4689. d) Liu, B.; Hu, X.-L.; Liu, J.; Zhao, Y-D. Huang, Z.-L. Tetrahedron Lett. 2007, 48, 5958-5962. e) Liu, B.; Zhang, H.-L.; Liu, J.; Zhao, Y.-D.; Luo, Q .-M.; Huang, Z.-L. J. Mater. Chem. 2007, 17, 2921-2929. f) Chen, D.; Zhong, C.; Dong, X.; Liu, Z.; Qin J. J. Mater. Chem. 2012, 22, 4343-4348. g) Li, L.; Ge, J.; Wu, H.; Xu, Q.-H.; Yao, S. Q. J. Am. Chem. Soc. 2012, 134, 12157-12167. h) Achelle, S.; Malval, J.-P.; Aloïse, S.; Barsella, A.; Spangenberg, A.; Akdas-Kilig, H.; Fillaut, J.-L.; Caro, B.; Robin-le Guen, F. ChemPhysChem 2013, doi: 10.1002/cphc.201300419.

${ }^{6}$ a) Hadad, C.; Achelle, S.; García-Martinez, J. C.; Rodriguez-López, J. J. Org. Chem. 2011, 76, 3837-3845. b) Hadad, C.; Achelle, S.; López-Solera, I.; García-Martinez, J. C.; Rodriguez-López, J. Dyes Pigm. 2013, 97, 230-237.

${ }^{7}$ Aranda, A. I.; Achelle, S.; Hammerer, F.; Mahuteau-Betzer, F.; Teulade-Fichou, M.-P. Dyes Pigm. 2012, 95, 400-407. 
${ }^{8}$ Achelle, S.; Barsella, A.; Baudequin, C.; Caro, B.; Robin-Le Guen, F. J. Org. Chem. 2012, 77, 4087-4096.

${ }^{9}$ a) Yaziji, V. ; Rodríguez, D.; Gutiérrez-de-Terán, H. ; Coelho, A.; Caamaño, O.; GarcíaMera, X.; Brea, J.; Loza, M. I.; Cadavid, M. I.; Sotelo, E. J. Med. Chem. 2011, 54, 457-471. b) Ouf, N. H.; Amr, A E.-G. E. Monatch. Chem. 2008, 139, 579-585. c) Yaziji, V.; Coelho, A.; El Maatougui, A.; Brea, J.; Loza, M. I.;Garcia-Mera, X.; Sotelo, E. J. Comb. Chem. 2009, 11, 519-522. d) Moustafa, A. H.; Saad, H. A.; Shehab, W. S.; El-Mobayed, M. M. Phosphorus, Sulfur Silicon Relat. Elem. 2008, 183, 115-135.

${ }^{10}$ a) Molander, G. A. ; Bernardi, C. R. J. Org. Chem. 2002, 67, 8424-8429. b) Large, J. M.; Clarke, M.; Williamson, D. M.; McDonard, E.; Collins, A. Synlett 2006, 861-864.

${ }^{11}$ Miyaura, N.; Suzuki, A. Chem. Rev. 1995, 95, 2457-2483.

${ }^{12}$ Littke, A. F.; Fu, G. C.; Angew. Chem. Int. Ed. 2002, 41, 4176-4211.

13 a) Schomaker, J.; Delia, T. J. J. Org. Chem. 2001, 66, 7125-7128. b) Delia, T. J.; Schomaker, J.; Kalinda, A. S. J. Heterocycl. Chem. 2006, 43, 127-131. c) Achelle, S.; Ramondenc, Y.; Marsais, F.; Plé, N. Eur. J. Org. Chem. 2008, 3129-3140. d) Achelle, S.; Plé, N.; Kreher, D.; Attias, A.-J.; Arfaoui, I.; Charra, F. Tetrahedron Lett. 2009, 50, 7055-7058.

${ }^{14}$ Vanden Eynde, J.-J.; Pascal, L.; Van Haverbeke, Y.; Dubois, P. Synth. Commun. 2001, 31 , 3167-3173.

${ }^{15} \mathrm{We}$ thank one of the reviewers for his help in the interpretation of this point.

${ }^{16}$ Wink, C.; Detert H. J. Phys. Org. Chem. 2013, 26, 144-150.

${ }^{17}$ Reichardt, C. Chem. Rev. 1994, 94, 2319-2358.

${ }^{18}$ See for example: a) Katan, C.; Terenziani, F.; Mongin, O.; Werts M. H. W.; Porres, L.; Pons, T.; Mertz, J.; Tretiak, S.; Blanchard-Desce, M. J. Phys. Chem. A 2005, 109, 3024-3027.

b) Lartia, R.; Allain, C.; Bordeau, G.; Schmidt, F. Fiorini-Debuischert, C.; Charra, F.; Teulade-Fichou, M.-P. J. Org. Chem. 2008, 73, 1732-1744. c) Panthi, K.; Adhikari, R. M.; 
Kinstle, T. H. J. Phys. Chem. A 2010, 114, 4542-4549. d) Cornec, A. S.; Baudequin, C.; Fiol-

Petit, C.; Plé, N.; Dupas, G.; Ramondenc, Y. Eur. J. Org. Chem. 2013, 1908-1915. 